\title{
The Impact of Costs And School Environment Against The Decision to Choose Schools Through School Image
}

\author{
Sumarno, Budiyanto, Marsudi Lestarinigsih \\ Sekolah Tinggi Ilmu Ekonomi Indonesia (STIESIA), Surabaya \\ sumarnoyym@gmail.com
}

\begin{tabular}{ll}
\hline Article History & Received : Jan $9^{\text {th }} 2021$ \\
& Revision : March $13^{\text {th }} 2021$ \\
& Publication : June $30^{\text {th }} 2021$ \\
\hline
\end{tabular}

\begin{abstract}
This study aims to analyze and test empirically: the effect of costs and the school environment on the decision to choose a school through the school's image at Insan Cendekia Mandiri Junior High School, Sidoarjo. This research uses a quantitative approach with the type of causality research. The population in this study were 295 parents of students, with a total sample of 75 people who were taken by accidental sampling. The data analysis technique was performed using inferential statistics consisting of path analysis, classical assumption test, model feasibility test and hypothesis testing. The results showed that first, school fees have a significant effect on the decision to choose a school at SMP Insan Cendekia Mandiri Sarirogo Sidoarjo. Second, the school environment has a significant effect on the decision to choose a school at Insan Cendekia Mandiri Middle School, Sidoarjo. Third, school fees have no significant effect on the decision to choose a school through the image of the school at Insan Cendekia Mandiri Junior High School, Sidoarjo. And fourth, the school environment has no significant effect on the decision to choose a school through the image of the school at Insan Cendekia Mandiri Junior High School, Sidoarjo.
\end{abstract}

Keywords: Cost, school environment, school image, the decision

\section{INTRODUCTION}

The rapid development of science and technology and the rapid dynamics of society today are a challenge for all types of industries to compete in order to be able to penetrate customers, including industries in the field of education services. Service organizations have shifted the service paradigm from comparative advantage to competitive advantage. This shift requires that service activities need to be directed with the right strategy. The strategy will determine the strategic position of an organization and the ability to adapt to the changing environment in the educational organization.

Various services and educational services are currently offered by educational institutions to prospective students and people with excellence in each educational 
institution, such as full day school, boarding school, nature school, character-based school, entrepreneur-based school and others. From the advantages that exist in each educational institution they are competitive to attract prospective students and their parents in order to become customers.

Competitive advantages for educational institutions include the ability to attract parents of prospective students and obtain students to the maximum, quotas of students that can be met annually, maximizing resources, infrastructure facilities, potentials and availability of funds to finance the programs - educational programs that have been planned, such conditions are always pursued by educational institutions to maintain their existence and sustainability of operational activities. But it turns out that not all the advantages offered by educational institutions are able to attract new parents and prospective students. This is because every parent or prospective student has their own considerations in making decisions on choosing a school. This causes each educational institution not necessarily able to meet the quota target in the acceptance of new students every year as expected. Buchari stated that if an educational institution is unable to market its output due to quality standards that do not meet expectations, then the output of services offered will not sell. This will result in the school going backwards, deserted and eventually having to close (Alma, 2008, p. 98)

The decision to choose a school is a decision that is sometimes not easy for parents. People are now given many alternative educational institutions ranging from religious nuances to the general and all of them have the advantage of foreign m (Noor, 2019, p. 28). Interesting packaged school programs are also a bargaining force for a school (Noor, 2017b, p. 67)

Parents in making decisions through the selection of various schools taking into account the factors that exist based on confidence. The hope is the decision he took is the right decision. The decision to choose a school is a process of parents in determining the choice of schools from various school options that exist with various considerations and factors that exist in the parents. According to research conducted by Rosha, Wati and Dharma that factors that affect parents in determining where their children attend school are the quality of teaching, teacher quality, school location, religious education, school facilities, school image, school costs, school environment, and school safety. Of these considerations, the cost and image of the school are significant factors in the decision of parents in choosing a school (Rosha et al., 2017, p. 139)

Cost is an important instrument for an organization or individual to achieve a desired goal. Without cost, the goals of organizations or individuals are difficult to realize because of the costs associated with services, facilities, and quality. The cost is a sacrifice of economic resources measured in units of money that have occurred or that are likely to happen for a specific purpose (Bastian, 2015, p. 339) Referring to Government Regulation (PP) No. 48 Year 2008 on Education Funding, that the 
cost is a personal cost incurred by the family or parents of the learners (Government Regulation(PP) No. 48 Year 2008 on Education Funding, 2008) In the context of school, school fees refer to indicators of affordability of costs by the community, cost competitiveness and suitability of costs with services (Kotler \&Armstrong, 2012)

In addition, consideration in deciding to choose a school is a factor in the school environment. School environment is everything around the child, in formal education, both in the form of objects, events that occur and school conditions that can have a strong influence on the child (Anshari, 1983, p. 90) The school environment is one of the factors that can influence the growth and development of children specially to hone their intelligence (Dalyono, 2015, p. 131). Environment, behavior and human influence each other (Noor, 2017a, p. 136). The position of the school environment is after the family environment because the educational environment that individuals get is from the family environment (Hasbullah, 2013, p. 36). The school environment includes teacher interaction with students, interaction of learners with fellow students, pre-facilities and school discipline (Slameto, 2010, p. 64).

Another important factor that influences decisions in choosing a school is the image of the school. Image or image is related to the reputation of a brand or an organization. The image of the organization is described as an overall impression made in people's minds about an organization. The image represents the overall impression made publicly of the company and its products (Kotler \&Keller, 2007, p. 94). The image of an organization like a school as a whole is built by many components. Some of them are the quality of graduates, the success of management, the behavior of members of the organization, and their social responsibility (Kurliyatin et al., 2017, p. 129). In addition, there are also supporting components of the school's image such as school personality (personality), school reputation (reputation), values embraced by the school (value) and school identity (corporate identity) (Harris, 2008, p. 71).

In a previous study conducted by Saputri, Putri and Rini obtained the results that the decision of parents to choose a school is based on factors of teacher quality, religious education applied in schools, facilities, school fees, hygiene and tranquility conditions of the school environment, school safety, school image, school achievement and student achievement, school location, extracurricular activities, promotions conducted by the school, quality of service in supporting teaching and learning activities, culture applied in daily schools, and customer quality (Saputri et al., 2018, p. 153) In line with previous research, Khasanah mentions factors that determine the choice of parents in choosing a school, among others, school location, customer satisfaction and school culture (Khasanah, 2012, p. 137).

This research aims to empirically test and analyze several things. First, the effect of school fees on the decision to choose a school. This is based on the 
assumption that the strategy of costing by the school has a big role in attracting parents because each parent has different economic abilities. Instead they compared the cost of one school to another. However, for some parents there are not too much concern about the amount of costs that must be incurred because they already believe they will get the benefits or quality provided by the school in accordance with the expectations and quality of the school for their child.

Second, the influence of the school environment on the decision to choose a school. This is based on the assumption that the school environment is very large role in the process of teaching and learning activities to achieve educational goals. Good relations among school residents, enforcement of discipline, adequate infrastructure, clean environment, neat, comfortable will motivate students to be more active and enthusiastic in learning. The school environment has a significant impact on students' learning motivation (Akbar \&Permana, 2019, p. 1). The school environment will have an impact on aspects of student education, the only result of student learning (Martina et al., 2019, p. 164).

Third, The effect of school fees on the decision to choose a school through the image of the school. The assumption is based on the image of the school influenced by the cost of school and the decision of parents to choose a school is influenced by the image of the school. The relationship between the variable cost of scholastic and the image of the school as research has been done before conducted by Leksono and Herwin that there is an influence of costs on the image (brand image) and purchasing decisions (Leksono \&Herwin, 2017, p. 381). School fees affect the image of the school, and the image of the school influences parents' decision to choose a school (Rosha et al., 2017, p. 139).

Andfourth, the influence of the school environment on the decision to choose a school through the image of the school. The assumption is that brand image influences purchasing decisions. The environment has a significant influence on its brand image because it can effectively strengthen the company's brand image. environment of a place has a significant influence on its brand image. The environment can effectively strengthen the company's brand image. This means that a school environment will have a significant influence on the image of the school, as the school environment can effectively strengthen the image of the school (Booms \&Bitner, 1982, p. 35).

\section{METHODS}

This research was conducted at SMP Insan Cendekia Mandiri, Jl. Raya Sarirogo No. 1 Sidoarjo. This study uses quantitative approach, which is a type of research that emphasizes the testing of theories through the measurement of research variables with numbers that require data analysis with statistical procedures,namely testing the influence of cost and school environment on the 
decision of parents to choose a school through the image of the school at SMP ICM Sarirogo, Sidoarjo (Machali, 2018, p. 21).

The population of this study is the parents of smp SMP Insan Cendekia Mandiri, Sidoarjo which amounted to 295 people and in the end determined as many as the number of respondents of this study as many as 75 people with the determination based on the formula Slovin. (J. Noor, 2016, p. 138) Sampling techniques used are accidential sampling,i.e. researchers determine respondents by chance and feel suitable fork to be used as a datasource (Sugiyono, 2016, p. 124).

Data collection using questionnaires that use the Likert scale in its application directly to selected respondents, namely parents of students of SMP Insan Cendekia Mandiri Sidoarjo. The questionnaires each revealed two independent variables, one mediation and one dependent variable, namely Independent Variables: School Fees (BS), School Environment (LS), Mediation Variables: School Image (CS), Dependent Variables: School Mmilih Decisions (KMS). Data analysis techniques used in this study using inferential statistical methods include; Path analysis, classic Assumption Test, Model Feasibility Test and Hypothesis Test.

Path analysis (Path Analysis) is used to test the influence of mediator variables i.e. school image variables. The path analysis image asinfigure 1.

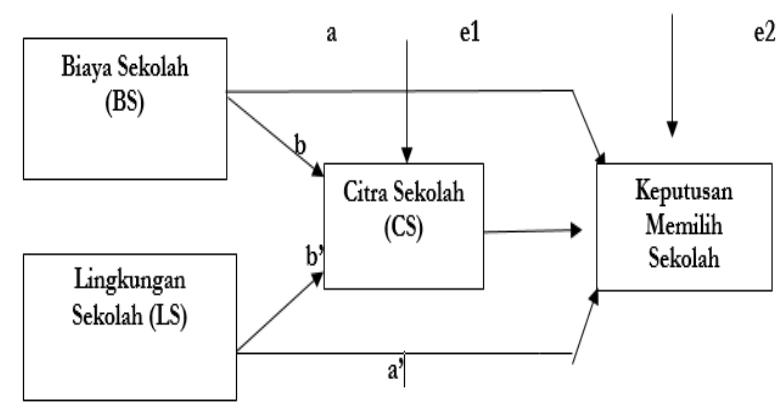

Figure 1 : Path Analysis

Through the illustration, it is illustrated that The School Fee (BS) has a direct relationship with the Decision to Choose a School (KMS), equal to (a), the School Fee (BS) also has an indirect relationship with the Decision to Choose a School (KMS), through the School Image (CS), equal to (b) new to the Decision to Choose a School (KMS), equal to (c). Furthermore, the School Environment (LS) has a direct relationship with the Decision to Choose a School (KMS), equal to (a'). In addition, the School Environment (LS) has an indirect relationship with the Decision to Choose a School (KMS), through the School Image (CS) is equal to the new (b') to the Decision to Choose a School ( KMS ), equal to (c ). From the analysis model of the above path can be expressed in the form of structural equations, namely regression equations as follows:

$\mathrm{CS}=\mathrm{bBS}+\mathrm{b}^{\prime} \mathrm{LS}+\mathrm{E}_{1}$ 
$\mathrm{KMS}=\mathrm{aBS}+\mathrm{a}^{\prime} \mathrm{LS}+\mathrm{cCS}+\epsilon_{2}$

information:

$\mathrm{CS}=$ School Image, mediation variable

KMS $=$ Decision to choose a school, dependent variable

$\beta=\quad$ Variable coefficient of influence value

BS $=$ Tuition Fees, independent variables

LS = School Environment, independent variable

$1,2=$ Uninterrupted Variable./Default error

The classic assumption test consists of: Normality Test to test whether in the regression model, the disruptive or residual variable has a normal distribution. Multicolerity test aims to test whether in the regression model there is a correlation between free variables (independent). The cut off value commonly used to indicate multicority is a Tolerance value $\geq 0.10$ or equal to the VIF value $\leq 10$.

The Ordinary least square test aims to test whether in the regression model there is a variant inequality from residual one observation toanother. The way to detect the presence or absence of ordinary least square is tosee the Plot Graph between the predicted value of a bound variable (dependent) namely "Standardized Predicted Value (ZPRED)" with its residual "Studentized Residual (SRESID)". (Ghozali, 2005, p. 139)

Determination Coefficient Test ( $\mathrm{R} \mathrm{Test}^{2}$ ) is a tool to measure how far the model can go in describing variations in dependent variables. A small Coefficient of determination $\left(\mathrm{R}^{2}\right)$ means the ability of independent variables to describe dependent variable variations is very limited. A model feasibility test ( $F$ test) is a model test that shows whether the regression model is feasible for further processing. Testing was conducted using a significant level of $0.05(\alpha=5 \%)$. Terms of acceptance or rejection as follows: (a) If the value of significance $F>0.05$ then the research model can be said to be unfit. (b) If the significance value of $F \leq 0.05$ then this research model can be said to be feasible.

After conducting various tests of normality and feasibility of the model then the next is to conduct hypothesis testing. Hypothesis tests are used to explain the direction of the relationship between independent variables and their dependent variables.

\section{RESULTS AND DISCUSSION \\ Statistical Analysis Results}

Analysis of inferential statistics in this study includes; Path analysis, classic Assumption Test, Model Feasibility Test and Hypothesis Test.

\section{Path Analysis Results}


The results of path analysis (path analisys) in this study as in the path picture (path analysis) in this study as follows:

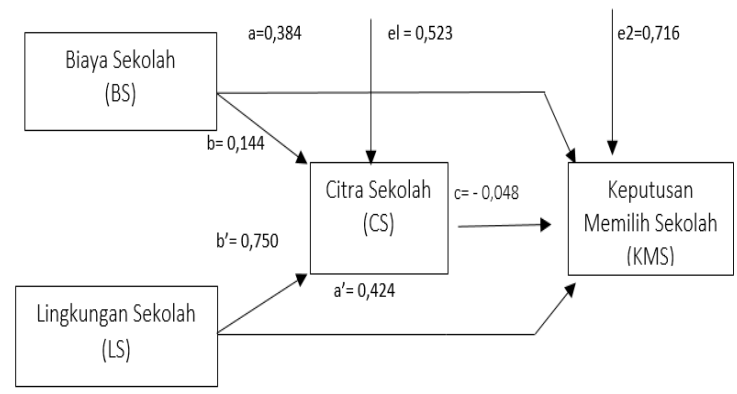

Figure 2 : Path Analysis Results

Based on the results of the analysis of the path on known coefficient values of paths for each independent variable against dependent variables are as follows: From the equation model 1:

The standardized coefficient value for the School Fee (BS) variable against the positive school image (CS) was 0.144 which indicates a direct relationship. The standardized coefficient value for the School Environment (LS) variable against the Positive School Image (CS) of 0.750 indicates a direct relationship.

\section{From the equation model 2:}

The standardized coefficient score for the School Cost variable (BS) against a positive school choosing decision (KMS) of 0.384 which indicates a direct relationship, standardized coefficient value for School Environment (LS) variable against positive school selectputusa (KMS) of 0.424 which indicates unidirectional relationship, and standardized coefficient value for School Image variable (CS) against negative school choosing decision (KMS) of -0.048 indicating unidirectional relationship.

To calculate the value $\mathrm{e} 1=\sqrt{1}-$ Rsquare $=\sqrt{1-0726}=0.523$, while untuk calculate the value $\mathrm{e} 2=\sqrt{1}-$ Rsquare $=\sqrt{1-0487}=0.7162$.

\section{Classic Assumption Test Results}

\section{Normality Test Results}

The results of normality test in this study are presented as follows: 


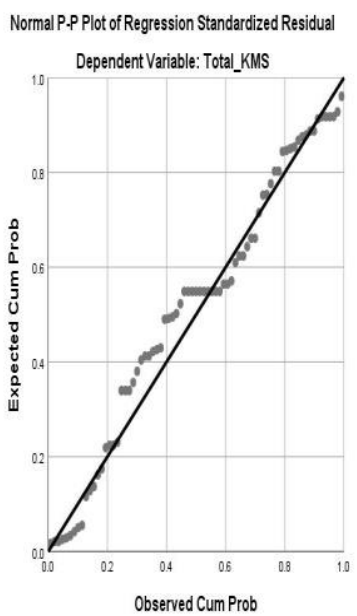

Figure 3 : Pp Plot Regresion Result

Dari normality test results can be known that the data spread around the diagonal line and follow the diagonal line direction this means that the data in this study is normally distributed

\section{Multicolineritas Test Results}

The results of multicolineritas test in this study as stated in table 1 as follows:

Table 1:

Multicolineritas Test Results

\begin{tabular}{|l|r|r|l|}
\hline \multicolumn{4}{|c|}{ Coefficients $^{\mathbf{a}}$} \\
\hline \multirow{2}{*}{ variabel } & \multicolumn{2}{|c|}{ Collinearity Statistics } & \multirow{2}{*}{ Keterangan } \\
\cline { 2 - 3 } & Tolerance & \multicolumn{1}{|c|}{ VIF } & \\
\hline Biaya Sekolah (BS) & 0.538 & 1.859 & Bebas Multikolinearitas \\
\hline $\begin{array}{l}\text { Lingkungan } \\
\text { Sekolah (LS) }\end{array}$ & 0.261 & 3.838 & Bebas Multikolinearitas \\
\hline Citra Sekolah (CS) & 0.274 & 3.655 & Bebas Multikolinearitas \\
\hline a. Dependent Variable: Keputusan_Memilih_Sekolah \\
\hline Sumber: Olahan
\end{tabular}

Based on table 1 it can be known that the tolerance figure $>0.10$ and the Variance Inflation Factor (VIF) value < 10. This means that the model used in this study found no correlation between free or free variables from multicolineritas. 


\section{Ordinary least square Test Results}

Ordinary least square test results in this study as presented as follows:

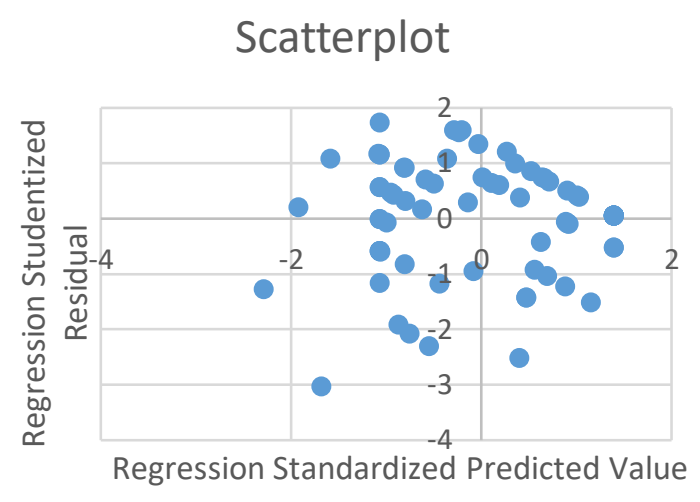

Figure 4 :Scatterplot Chart Results

Based on the results of heteroskedastisity test seen the above points spread randomly does not form a certain pattern that is clear, and spread above or below the number 0 on the $\mathrm{Y}$ axis, it can be concluded that there is no heterokedastisity disorder in the regeresi model.

\section{Model Feasibility Test Results}

\section{Determination CoefficientTest Result $\left(R^{2}\right)$}

Results of the coefficient of determination $\left(\mathrm{R}^{2}\right)$ as in tables 2 and 3

Model 1:

School Fees (BS), School Environment (LS) to School Image (CS)

Table 2

Determination CoefficientTest Result $\left(\mathrm{R}^{2}\right)$

\begin{tabular}{|c|c|c|c|c|}
\hline \multicolumn{5}{|c|}{ Model Summary } \\
\hline Model & $\mathrm{R}$ & R Square & Adjusted R Square & $\begin{array}{l}\text { Std. Error of the } \\
\text { Estimate }\end{array}$ \\
\hline 1 & $.852^{2}$ & .726 & .719 & 1.613 \\
\hline \multicolumn{5}{|c|}{ a. Predictors: (Constant), Total_LS, Total_BS } \\
\hline
\end{tabular}

Based on table 2 shows that the value of R Square 0.726 or $72.6 \%$ which means the effect of school fees (BS) and school environment (LS) on the image of the school (CS) is 0.726 or $72.6 \%$ and the remaining $27.4 \%$ is due to other variables outside the model. 


\section{Model 2:}

School Fees (BS), School Environment (LS) and School Image (CS) against The Decision to Choose a School ( KMS )

Table 3

Determination CoefficientTest Result $\left(\mathrm{R}^{2}\right)$

\begin{tabular}{|c|c|c|c|c|}
\hline \multicolumn{5}{|c|}{ Model Summary } \\
\hline Model & $\mathrm{R}$ & R Square & Adjusted R Square & $\begin{array}{l}\text { Std. Error of the } \\
\text { Estimate }\end{array}$ \\
\hline 2 & $.698^{2}$ & .487 & .466 & 1.864 \\
\hline \multicolumn{5}{|c|}{ a. Predictors: (Constant), Total_CS, Total_BS, Total_LS } \\
\hline
\end{tabular}

Based on table 3, it shows that the value of R Square 0.487 or $48.7 \%$ which means the influence of variable school fees (BS), school environment (LS), and school image (CS) on the decision to choose a school (KMS) is 0.487 or $48.7 \%$ and the remaining $51.3 \%$ is due to other variables outside the model.

\section{Model Feasibility Test Results ( F Test )}

The results of the model feasibility significance test ( Test F ) as in tables 4 and 5

Model 1:

School Fees (BS), School Environment (LS) to School Image (CS)

Table 4 :

Model Feasibility Test Results ( F Test )

\begin{tabular}{|c|c|c|c|c|c|c|}
\hline \multicolumn{7}{|c|}{ ANOVA $^{a}$} \\
\hline \multicolumn{2}{|r|}{ Model } & $\begin{array}{l}\text { Sum of } \\
\text { Squares }\end{array}$ & df & Mean Square & $\mathrm{F}$ & Sig. \\
\hline \multirow[t]{3}{*}{1} & Regression & 497.086 & 2 & 248.543 & 95.576 & $.000^{6}$ \\
\hline & Residual & 187.234 & 72 & 2.600 & & \\
\hline & Total & 684.320 & 74 & & & \\
\hline \multicolumn{7}{|c|}{ a. Dependent Variable: Total_CS } \\
\hline \multicolumn{7}{|c|}{ b. Predictors: (Constant), Total_LS, Total_BS } \\
\hline
\end{tabular}

Based on table 4 showing a value of $\mathrm{F}$ significance of $0.00,<0.05$, this means that the cost of school (BS), school environment (LS) together is based on the image of the school (CS) and the model of decent structure.

Model 2:

School fees (BS), School environment (LS) and School image (CS) against the decision to choose a school ( KMS) 
Table 5

Model Feasibility Test Results ( F Test)

\begin{tabular}{|c|c|c|c|c|c|c|}
\hline \multicolumn{7}{|c|}{ ANOVA $^{a}$} \\
\hline \multicolumn{2}{|c|}{ Model } & $\begin{array}{l}\text { Sum of } \\
\text { Squares }\end{array}$ & df & Mean Square & F & Sig. \\
\hline \multirow[t]{3}{*}{2} & Regression & 234.475 & 3 & 78.158 & 22.496 & $.000^{b}$ \\
\hline & Residual & 246.672 & 71 & 3.474 & & \\
\hline & Total & 481.147 & 74 & & & \\
\hline \multicolumn{7}{|c|}{ a. Dependent Variable: Total_KMS } \\
\hline \multicolumn{7}{|c|}{ b. Predictors: (Constant), Total_CS, Total_BS, Total_LS } \\
\hline
\end{tabular}

Based on table 5 showing that the value of significance $F$ is $0.00,<0.05$, It is based on school costs (BS), school environment (LS), and school image (CS) jointly influence the decision to choose a school (KMS) and the model of decent structure.

\section{Hypothesis Test Results}

Individual Parameter Signification Test Results ( $\mathrm{t}$ Test)

In this study, researchers have prepared four hypotheses that want to be tested, namely:

H1: School fees affect school choice decisions

H2: School Environment influences school choosing decisions

H3: School fees affect school choice decisions through school image

H4: The school environment influences the decision to choose aschoolthrough the image of the school

Table 6

Hypothesis Test Results

\begin{tabular}{|c|c|c|c|c|c|}
\hline \multicolumn{6}{|c|}{ Coefficients $^{\mathrm{a}}$} \\
\hline \multirow[b]{2}{*}{ Model } & \multicolumn{2}{|c|}{$\begin{array}{c}\text { Unstandardized } \\
\text { Coefficients }\end{array}$} & \multirow{2}{*}{$\begin{array}{l}\text { Standardized } \\
\text { Coefficients } \\
\text { Beta }\end{array}$} & \multirow[b]{2}{*}{$\mathrm{t}$} & \multirow[b]{2}{*}{ Sig. } \\
\hline & B & Std. Error & & & \\
\hline (Constant) & 7.894 & 2.459 & & 3.211 & .002 \\
\hline Total_BS & .271 & .081 & .377 & 3.346 & .001 \\
\hline Total_LS & .275 & .080 & .388 & 3.440 & .001 \\
\hline a. Dependent Varia & otal_KMS & & & & \\
\hline
\end{tabular}

Based on table 6 known school fees (BS) significance value t of $0.01<0.05$ indicates that the influence of school fees (BS) on the decision to choose a school (KMS) issignificant, thus H1:accepted.

As for the school environment (LS) the significance value of $t$ of $0.01<0.05$ indicates that the influence of school environment variables (LS) on the decision to choose a school (KMS) is significant, with demikain H2: accepted. 
To test $\mathrm{H} 3$ and $\mathrm{H} 4$ is done by means of mediation variable checking with coefficient difference approach, the test result for hypothetical mediation variable test 3 as in figure 4.4 which is based on table 6 , table 7 and table 8 .

Table 7

Hypothesis Test Results

\begin{tabular}{|c|c|c|c|c|c|c|}
\hline \multicolumn{7}{|c|}{ Coefficients $^{2}$} \\
\hline \multirow{2}{*}{\multicolumn{2}{|c|}{ Model }} & \multicolumn{2}{|c|}{$\begin{array}{l}\text { Unstandardized } \\
\text { Coefficients }\end{array}$} & \multirow{2}{*}{$\begin{array}{c}\text { Standardized } \\
\text { Coefficients } \\
\text { Beta }\end{array}$} & \multirow[b]{2}{*}{$\mathrm{t}$} & \multirow[b]{2}{*}{ Sig. } \\
\hline & & B & Std. Error & & & \\
\hline \multirow[t]{3}{*}{2} & (Constant) & 7.982 & 2.493 & & 3.202 & .002 \\
\hline & Total_BS & .276 & .083 & .384 & 3.315 & .001 \\
\hline & Total_LS & .301 & .118 & .424 & 2.546 & .013 \\
\hline & Total_CS & -.040 & .136 & -.048 & -.295 & .769 \\
\hline & at Varia & al_KM & & & & \\
\hline
\end{tabular}

Table 8

Hypothesis Test Results

\begin{tabular}{|c|c|c|c|c|c|c|}
\hline \multicolumn{7}{|c|}{ Coefficients $^{\mathrm{a}}$} \\
\hline \multirow{2}{*}{\multicolumn{2}{|c|}{ Model }} & \multicolumn{2}{|c|}{$\begin{array}{c}\text { Unstandardized } \\
\text { Coefficients }\end{array}$} & $\begin{array}{l}\text { Standardized } \\
\text { Coefficients }\end{array}$ & \multirow[b]{2}{*}{$\mathrm{t}$} & \multirow[b]{2}{*}{ Sig. } \\
\hline & & B & Std. Error & Beta & & \\
\hline \multirow[t]{3}{*}{1} & (Constant) & 2.193 & 2.141 & & 1.025 & .309 \\
\hline & Total_BS & .124 & .071 & .144 & 1.753 & .084 \\
\hline & Total_LS & .634 & .070 & .750 & 9.109 & .000 \\
\hline \multicolumn{7}{|c|}{ a. Dependent Variable: Total_CS } \\
\hline
\end{tabular}

The results of the examination of mediation variables with a coefficient difference approach for hypothesis 3 are as follows:

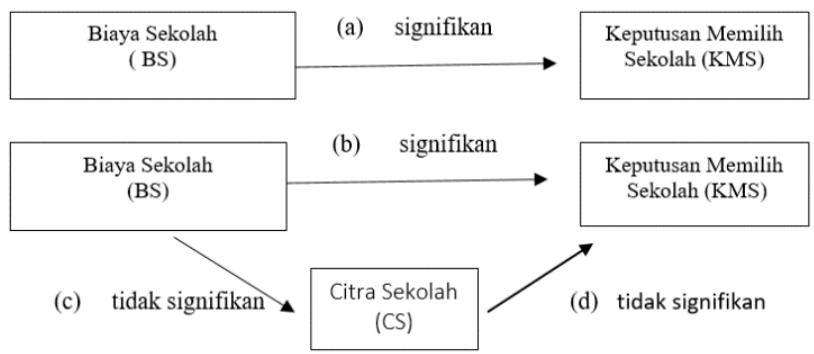

Figure 4 : Hypothetical examination result 3

The exposure of the picture is as follows:

a) (a) School fees (BS) have a significant effect on the decision to choose a school (KMS) without involving the image of the school (table 6) 
b) (b) School fees (BS) have a significant effect on the decision to choose a school (KMS) by involving the image of the school(CS) as mediation (table 7)

c) (c) School fees (BS) have no significant effect on the image of the school (table 8)

d) (d) The image of the school ( CS) has no significant effect on the decision to choose a school (KMS) ( table 7)

From the results of the examination, it is known that (c) the cost of the school to the image of the school (CS), and (d)the image of the school (CS) to the decision to choose a school (KMS) has no significant effect on the decision to choose the school, then hypothesis 3 is rejected.

The results of the examination of mediation variables with the approach of coefficient differences for hypothesis 4 are as follows:

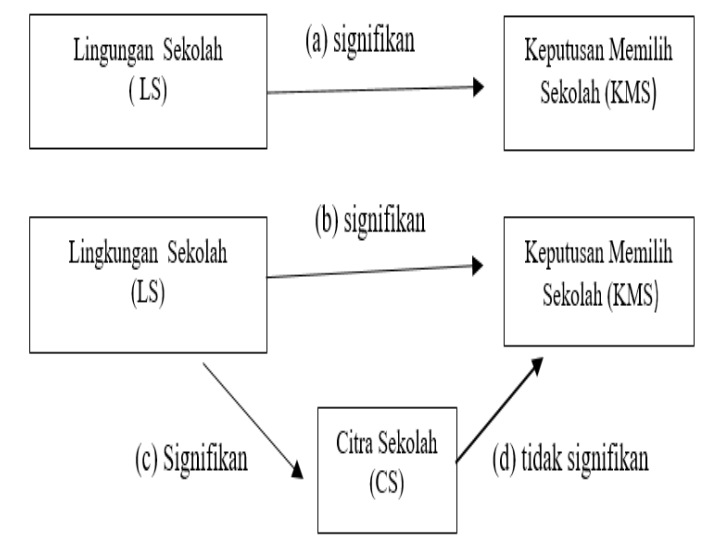

Figure 5: Hypothetical test result 4

The exposure of the picture is as follows:

a) (a) The school environment (LS) has a significant effect on the decision to choose a school (KMS) without involving the image of the school (table6)

b) (b) The school environment (LS) has a significant effect on the decision to select a school (KMS) by involving the image of the school (CS) as mediation (table 7)

c) (c) The school environment (LS) has a significant impact on the image of the school (table 8

d) (d) The image of the school (CS) has no significant effect on the decision to choose a school (KMS) (table 7)

From the results of the examination it is known that (d) the image of the school has no significant effect on the decision to choose a school (KMS), then hypothesis 4 is rejected. 


\section{School Fees Have a Significant Impact on School Choice Decisions}

The test results showed that school fees proved to have a positive and significant effect on the decision to choose a school as evidenced by table 6 . Thisreflects the similarity between the cost of schooling by parents and the services and benefits that the school provides to students into consideration of parents in the decision to choose a school. Therefore it is important for the school to continuously improve its services and benefits tostudents and theirmasters.

School cost factor is the main factor for parents of students, because each parent has different abilities, in general the income of parents is not only used for education costs, but also used to finance other needs such as; needs of food, clothing, health and others. For some parents the cost of education is no longer an issue because of their economic ability and they have realized that the costs incurred are proportional to the facilities and services obtained from the school, but for the other parents the cost of schooling is still a determining factor in the decision to choose a school, because of the limitations of ability in the economy, so that parents still compare the cost of one school with another school when deciding to choose a school. This is in line with the results of Rosha, Wati and Dharma researches the factors that influence parents in making decisions on choosing SDI AL Azhar 32 Padang school, whose results show that school cost factors are a significant factor in influencing parents in decision making to choose a school. (Rosha et al., 2017, p. 139)

\section{School Environment Has a Significant Impact on School Choosing Decisions}

The test results showed that the school environment proved to have a positive and significant effect on the decision to choose a school as evidenced by table 6 . Hal this reflects an orderly school environment, which there are activities of students learning groups, school communication with good parents into consideration of parents in the decision to choose a school. Therefore, it is important for the school to continuously improve the quality of the school environment, including by improving discipline by all school personnel, fun activities with students and improving school communication with parents.

The school environment consists of a social and non-social environment, a school social environment, including educators, educational personnel, classmates, and school employees, while the non-social environment of the school includes the school building and itslocation, learning tools, and learning time (Shah, 2016, p. 135). Environment becomes a means to internalize important values dnature of one's learning process (Nooret al., 2021, p. 9). The results of Akbar and Permana's research mention that the school environment has a significant influence on the learning motivation of students (Akbar \&Permana, 2019, p. 1). Similarly, research conducted by Martina, Khadija and Syarnubi has a significant influence between the sekolah environment on student learningoutcomes (Martina et al., 2019, p. 164). 
From the two empirical studies showed that the school environment had a significant influence on the motivation and learning achievements of learners. This will certainly be a consideration for parents in making decisions in choosing a school.

\section{School fees have an insignificant effect on school choice decisions through the School's image}

The results showed that the cost of the school is insignificant to the decision to choose a school through the image of the school, this is evidenced by the results of a mediation variable examination with a coefficient difference approach in figure 5. School fees have to do with the decision to choose a school, where school fees reflect the similarity between the cost of schooling spent by parents and the services and benefits that the school provides to students. In determining the cost of school the element of consideration is the affordability of costs, fairness compared to others, in balance with the services and benefits provided, all of which will have an impact on the image of the school.

For some parents, tuition fees are a major factor due to economic limitations, so in the decision to choose a school still compares the cost of one school with another because it does not connect how the image of the school they choose. As for some parents, school fees are no longer an issue due to economic inadeficiency and they have realized that the costs they spend are comparable to the facilities, services, benefits received and the image of the school they perceive.

The results of this study are different from the research of Erlitna and Soesanto that Price can influence the purchase decision of a product, which occurs because of the role of the brand image as a mediation variable. (Erlitna \&Soesanto, 2018, p. 1)

\section{School Environment Has Insignificant Effect on School Choosing Decisions Through School Image}

The results of this study showed that the school environment had no significant effect on the decision to choose a school through the image of the school, this is evidenced by the results of a mediation variable examination with a coefficient difference approach in figure 5 . The environment is often identified with imagery, so a good environment is identical to a good image and vice versa. The school environment consists of a social and non-social environment, a school social environment, including educators, educational personnel, classmates, and school employees, while the non-social environment of the school includes the school building and its location,learning tools, and learning time (Shah, 2016, p. 135). A good school environment will have an impact on the image of the school, the image of the school influences the decision to choose the school. 
The image of the school is built through the reputation of the school, how the school produces qualified graduates, maintains integrity, provides maximum service and upholds the values of truth held firmly and taught and developed in schools consistently and responsibly, as well as the attributes of the school that are easily known and felt by the community as good attributes and positive. Although the public's assessment of the image of an educational institution varies, there is a general perception created in the community of the image of an educational institution, and this image is the reference of the community in assessing an educational institution. The results of this study are not in line with the results of research conducted by Rosha, Wati and Dharma which states, that the image of the school is a significant factor in the decision of parents in choosing a school (Rosha et al., 2017, p. 139).

\section{CONCLUSION}

Based on this research aims to test the influence of costs and the school environment on the decision to choose a school through the image of the school found that first, school fees have a significant effect on the decision to choose a school at SMP Insan Cendekia Mandiri Sarirogo Sidoarjo. Second, the school environment has a significant influence on the decision to choose a school at SMP Insan Cendekia Mandiri, Sidoarjo. Third, school fees have an insignificant effect on the decision to choose a school through the image of the school at SMP Insan Cendekia Mandiri, Sidoarjo. And fourth, the school environment has no significant effect on the decision to choose a school through the image of the school at SMP Insan Cendekia Mandiri, Sidoarjo.

But there are limitations that exist in this study, among which is that this study only examines the cost, environment and image of the school that influences the decision to choose a school. however, it is possible that there are other factors that can influence the decision to choose a school, such as cultural factors, school location, security, religious lessons, personal competence, and services and community beliefs that can be researched. This means that this research still needs a lot of improvement so that in the future the results can be maximized.

\section{REFERENCE}

Akbar, T., \& Permana, P. S. (2019). Pengaruh Lingkungan SekolahDan Teman Sebaya Terhadap Motivasi Belajar Siswa Kelas IX SMP Yapia Parung. Jurnal Ilmiah Humanika, 2(2), 1-10.

Alma, B. (2004). Manajemen Pemasaran Dan Pemasaran Jasa. In Edisi Kelima cetakan Revisi, Bandung: Alfabeta. https://doi.org/10.1016/S01406736(79)90622-6

Anshari, H. (1983). Pengantar Ilmu Pendidikan. Usaha Nasional. 
Bastian, I. (2015). Akuntansi Sektor Publik: Suatu Pengantar. Erlangga.

Booms, B. H., \& Bitner, M. J. (1982). Marketing services by managing the environment. Cornell Hotel and Restaurant Administration Quarterly, 23(1), 35-40. https://doi.org/10.1177/001088048202300107

Dalyono, M. (2015). Psikologi Pendidikan. Rineka Cipta.

Erlitna, K. G., \& Soesanto, H. (2018). Analisis Pengaruh Harga, Kualitas Produk dan Positive Word of Mouth Terhadap Keputusan Pembelian dengan Brand Image sebagai Variabel Intervening (Studi Pada Pengguna Iphone di Fakultas Kedokteran Universitas Diponegoro). Diponegoro Journal of Management, $7(4), 1-15$.

Ghozali, I. (2005). Aplikasi Analisis Multivariate Dengan Program SPSS, Edisi Keempat. Badan Penerbit Universitas Diponegoro.

Harris, T. L. (2008). The Marketer's Guide To Public Relations. John Wiley and Sons, Inc.

Hasbullah, H. (2013). Dasar-Dasar Ilmu Pendidikan. PT. RajaGrafindo Persada.

Khasanah, N. (2012). Faktor-faktor yang mempengaruhi orang tua dalam pengambilan keputusan memilih sekolah dasar swasta (SD virgo maria 2 dan SDIP. H. Soebandi Kecamatan Bawen Kabupaten Semarang). Satya Widya, 28(2), 137-146. https://doi.org/10.24246/j.sw.2012.v28.i2.p137-146

Kotler, P., \& Armstrong, G. (2012). Principles Of Marketing 14th edition. In New Jearsey: Pearson Education Inc. Pascasarjana UIN Sunan Ampel Surabaya.

Kotler, P., \& Keller, K. L. (2007). Marketing Management 12th Edition. Pearson.

Kurliyatin, A., Bafadal, I., \& Zulkarnain, W. (2017). Hubungan Citra Sekolah, Pelayanan Prima, Harapan Orangtua, dan Rasa Bangga Orangtua dengan Keputusan Orangtua Menentukan Sekolah untuk Anaknya. Ilmu Pendidikan: Jurnal Kajian Teori Dan Praktik Kependidikan, 2(2), 129-138. https://doi.org/10.17977/um027v2i22017p129

Leksono, R. B., \& Herwin, H. (2017). Pengaruh Harga Dan Promosi Grab Terhadap Brand Image Yang Mempengaruhi Keputusan Pembelian Konsumen Pengguna Transportasi Berbasis Online. Jurnal Riset Manajemen Dan Bisnis (JRMB) Fakultas Ekonomi UNIAT, 2(3), 381-390. https://doi.org/10.36226/jrmb.v2i3.72

Machali, I. (2018). Metode Penelitian Kuantitatif : Panduan Praktis Merencanakan, Mlekasanakan Dan Analisis Dalam Penelitian Kuantitatif. Prodi. Manajemen Pendidikan Islam UIN Sunan Kalijaga bekerjasama dengan Perkumpulan Program Studi Manajemen Pendidikan Islam (PPMPI).

Martina, M., Khodijah, N., \& Syarnubi, S. (2019). Pengaruh Lingkungan Sekolah Terhadap Hasil Belajar Siswa Pada Mata Pelajaran Pendidikan Agama Islam Di SMP Negeri 9 Tulung Selapan Kabupaten Oki. Jurnal PAI Raden Fatah, 1(2), 164-180.

Muhibbin, S. (2010). Psikologi pendidikan dengan pendekatan baru. Bandung: PT Remaja Rosdakarya.

Noor, J. (2016). Metodologi Penelitian: Skripsi, Tesis, Disertasi \& Karya Ilmiah. Prenada Media.

Noor, T. R. (2017a). Analisis Desain Fasilitas Umum Bagi Penyandang Disabilitas (Sebuah Analisis Psikologi Lingkungan). Journal An-Nafs: Kajian Penelitian 
Psikologi, 2(2), 133-150. https://doi.org/10.33367/psi.v2i2.438

Noor, T. R. (2017b). Manajemen Pendidikan Anak Melalui Program Outbound Di TK Al Muslim Surabaya. SELING: Jurnal Program Studi PGRA, 3(2), 64-75. https://doi.org/10.29062/seling.v3i2.120

Noor, T. R. (2019). Pendidikan Islam Sebagai Sebuah Sistem Di Era 4.0. TA'LIM: Jurnal Studi Pendidikan Islam, 2(2), 153-171. https://doi.org/10.29062/ta'lim.v2i2.1472

Noor, T. R., Inayati, I. N., \& Bakri, M. (2021). Majelis Taklim Sebagai Transformator Pendidikan, Ekonomi Dan Sosial Budaya Pada Komunitas Muslimah Urban. Tarbiyatuna: Jurnal Pendidikan Islam, 14(1), 1-19. https://doi.org/10.36835/tarbiyatuna.v14i1.797

Peraturan Pemerintah (PP) No. 48 Tahun 2008 tentang Pendanaan Pendidikan. (n.d.).

Rosha, Z., Wati, L., \& Dharma, S. (2017). Faktor-faktor yang Mempengaruhi Orang Tua dalam Pengambilan Keputusan Memilih Sekolah Dasar Islam Al-azhar 32 Padang. Jurnal Apresiasi Ekonomi, 5(3), 139-147. https://doi.org/10.31846/jae.v5i3.131

Saputri, R. D., Putri, R. A., \& Rini, E. F. (2018). Faktor-Faktor Yang Mempengaruhi Pemilihan Sekolah Dasar Dalam Mendukung Kota Surakarta Layak Anak. Region: Jurnal Pembangunan Wilayah Dan Perencanaan Partisipatif, 13(2), 152-168. https://doi.org/10.20961/region.v13i2.21172

Slameto, S. (2010). Belajar dan Faktor Yang Mempengaruhinya. Rineka Cipta.

Sugiyono, S. (2016). Metode Penelitian Pendidikan (Pendekatan Kuantitatif, Kualitatif dan R\&D). CV. Alfabeta. 